УДК 005.35:338.48]:177

Безкоровайна Л.В., д.п.н., доцент професор кафедри туризму та готельно-ресторанної справи Bezkorovaina L.V. , DSc in Pedagogic, Associate Professor, Professor of the Department of Tourism,Hotel and Restaurant Business https://orcid.org/0000-0001-9502-9604

\title{
КОРПОРАТИВНЕ УПРАВЛІННЯ В КОНКУРЕНТНОМУ ТУРИСТИЧНОМУ СЕРЕДОВИЩІ: ЕТИКА І КУЛЬТУРА ГОСТИННОСТІ
}

\author{
Запорізький національний університет
}

\begin{abstract}
У статті автором опрацьовано питання корпоративного управління в туризмі, бізнес-етики та корпоративної культури в індустрії гостинності та їх вплив на стратегію сталого розвитку та конкурентоспроможності готельного підприємства в ринкових умовах туристичного бізнес-середовища. Розкрито, що корпоративна політика залежить від стратегії глобального розвитку, згідно якої восьма ціль проголошує забезпечення сприяння сталості туризму, що позначається на створенні нових робочих місць, розвиткові місцевої культури і виробництві місцевої продукції; економічному зростанні; підвищенні ефективності економіки через новації та диверсифікацію послуг. Нині в Україні існує чималий запас ресурсів для розвитку туризму в багатьох сферах, а саме: гастро-, агро-, екотуризм; спортивний, культурний, освітній, діловий туризм; події та фестивалі, свята, МІСЕ (зустрічі, заохочення, конференції, заходи) тощо. Визначення поняття корпоративного управління в готельному бізнесі, роз'яснення політики корпоративної етики та культури, а також технології надання готельних послуг важливим завданням систем управління готельною індустрією для забезпечення конкурентоспроможності та ефективності в туристичному бізнес-середовищі. Адекватна глобальній стратегії розвитку, восьма мета стосується туристичної галузі та проголошує до 2030 року: забезпечення реалізації стратегій підтримки сталого туризму, що підтримує створення робочих місць, розвиток місцевої культури, місцеве виробництво; сприяє економічному зростанню, повній та продуктивній зайнятості всіх громадян; підтримка зростання валового внутрішнього продукту в найменш розвинених країнах; підняття продуктивності економіки за рахунок диверсифікації, модернізації, інноваційної діяльності. Прийнятий Глобальний договір ООН має унікальні перспективи налагодити співпрацю між промисловістю та організаціями з метою вироблення шляхів вирішення глобальних проблем. Глобальний договір ООН закликає компанії привести свої стратегії та діяльність у відповідність з десятьма загальними принципами прав людини, трудових відносин, довкілля та битви з корупцією, а ще здійснити заходи для реалізації завдань досягнення сталого розвитку. Десять принципів Глобального договору ООН, засновані на ключових конвенціях та деклараціях $\mathrm{OOH}$, були визнані та закріплені в численних міжурядових ухвалах та підсумкових документах, включаючи резолюції Генеральної Асамблеї. Підприємства гостинності повинні дотримуватися цих принципів у своїй діяльності та у формулюванні стратегій подальшого розвитку та ефективної практики.

Ключові слова: туризм, туристична інфраструктура, індустрія гостинності, корпоративне управління, бізнес-етика, бізнес-культура.
\end{abstract}

\section{CORPORATE GOVERNANCE IN A COMPETITIVE TOURIST ENVIRONMENT: ETHICS AND CULTURE OF HOSPITALITY}

\section{Zaporizhzhya National University}

The author analyzed the issues of corporate governance in tourism, business ethics and corporate culture in the hospitality industry and their impact on the strategy of sustainable development and competitiveness of the hotel business in the market environment of the tourism business environment. It is revealed that corporate policy depends on the strategy of global development, according to which the eighth goal proclaims the maintenance of sustainability of tourism, which affects the creation of new jobs, development of local culture and production of local products; economic growth; improving the efficiency of the economy through innovation and diversification of services. Today in Ukraine there is a strong potential for tourism development in many areas, namely: gastro-, agro-, ecotourism; sports, cultural, educational, business tourism; events and festivals, holidays, MICE (Meetings, Incentives, Conferences, Events), etc. Defining the concept of corporate governance in the hotel business, clarifying the policy of corporate ethics and culture, as well as the technology of providing hospitality services, is an important task of hotel industry management systems to ensure competitiveness and efficiency in the tourism business environment. Adequate to the global development strategy, the eighth goal concerns the tourism industry, 
and proclaims by 2030: ensuring the implementation of strategies to support sustainable tourism, which supports job creation, local culture development, local production; promotes economic growth, full and productive employment for all citizens; supporting the growth of gross domestic product in the least developed countries; increasing the productivity of the economy through diversification, modernization, innovation. The adopted UN Global Compact has unique opportunities to establish cooperation between industry and organizations in order to develop ways to solve global problems. The UN Global Compact calls on companies to bring their strategies and activities in line with the ten general principles of social rights, labor relationships, the environment and the fight against corruption, and to take steps to achieve social and sustainable development goals. The Ten Principles of the UN Global Compact, based on key United Nations conventions and declarations, have been recognized and enshrined in numerous intergovernmental purposes and outcome papers, including General Assembly resolutions. Hospitality enterprises must adhere to these principles in their activities and in defining strategies for further development and effective operation.

Key words: tourism, tourist infrastructure, hospitality industry, corporate governance, business ethics, business culture.

Постановка проблеми у загальному вигляді і її з важливими науковими та практичними завданнями. Туризм - це водночас: царина господарства, складний міжгалузевий комплекс, в якому створюється і продається туристичний продукт, та вид економічної діяльності товариства.

Підкреслимо, що туризм є важливим складником життя людей будь-якої країни через його безпосередній вплив на соціальні, культурні, освітні, економічні ланки господарського функціонування та їх міжнародні взаємовідносини.

Поняття «туризм» відзначається як комплексна система, що обіймає певні процеси, взаємозв'язки, взаємини, що формуються в ході подорожування, а також поліфункціональну практику 3 надання туристичних послуг, які призначено для задоволення вимог туристів [1, с. 49-50].

Отже, туризм - це мультидисциплінарне, багатофакторне явище, котре об'єднує такі важливі складники, як: інфраструктура, гостинність, керування, перебування, доброякісність туристичного обслуговування, охорона навколишнього оточення, підготовка фахових кадрів, транспорт, забезпечення безпеки подорожуючих [1, с. 54].

Зазначимо, що діяльність із туризму виконує певні функції, що позначаються на різноманітних ланках життєдіяльності людей, а саме:

- суспільні функції позначаються на розвиткові туризму як соціально-економічної структури, світових взаємовідносин і кооперації;

- культурологічні - характеризують розріст злагодженої особистості із полікультурним, цільним науковим світосприйняттям стосовно всесвітнього, інтернаціонального призначення туризму для розвиненого союзу людськості;

- особистісні функції позначаються на інтелектуальному, психологічному, фаховому розвиткові, становленні національного усвідомлення;

- гуманітарні функції визначають піднесення креативних здатностей особистості, ерудиції, стремління до самовдосконалення, поширювання знань;

- політичні функції позначаються на розумінні фаху в туристичній галузі як дієвого способу для забезпечення миру й порозуміння товариства [1, с. 27].

Тож, питання формулювання концепції корпоративного управління в готельному підприємстві, з'ясування засад політики корпоративної етики та культури, а також технології надання послуг із гостинності, є важливим завданням структур управління підприємств готельної індустрії для забезпечення конкурентноспроможності та ефективного функціонування в умовах туристичного бізнес-середовища.

Аналіз останніх досліджень, у яких започатковано вирішення проблеми. Значення туристичного бізнесу в загальному стані та тенденціях всесвітньої економіки, підвищенні ступеня зайнятості, диверсифікації та інноваційної діяльності у царині національної економіки, збереженні й розвитку культурного потенціалу, збереженні й забезпеченні екологічно нешкідливого навколишнього природного оточення, 
гармонізації взаємин між державами і людьми, здійснювання зовнішньої поведінки країни, підтверджено на державному рівні, що засвідчено в тезах Стратегії розвитку туризму та курортів до 2026 р. (2017), Концепції популяризації України у світі та просування інтересів України у світовому інформаційному просторі (2018)) та т. ін.

Поглиблені скерованості та правила до опрацювання стратегій сталого розвитку туризму загалом та готельної індустрії окремо, зображено в нормативно-законодавчих постановах і паперах багатоманітних сходинок, а саме: Законах України «Про туризм» (2015), «Про курорти» (2000); Осакській декларації тисячоліття (2001); Резолюції 70-ї сесії Генеральної Асамблеї ООН (2015) та ін.

Різні питання туризму та готельної справи розкрито у наукових працях вітчизняних: О. Бейдика, О. Любіцевої, Н. Маковецької, М. Мальської та ін. і зарубіжних: K. Аннару, Дж. Боуена, Ч. Голднера, П. Димитратоса, I. Зоріна, Т. Квартальнова, Р. Макінтоша, Е. Плакойяннакі, Б. Рітчі та ін. дослідників.

3 огляду на опрацьовані теоретичні засади, слід акцентувати, що вимоги туристичної галузі в нинішніх всесвітніх угодах значною мірою зосереджено на закономірності тотожного кадрового забезпечення всіх шляхів розросту та різновидів туризму. Основоположні суперечності позначаються, по-перше, на характерних багатопрофільних рисах туристичної індустрії, що, певно, вимагає професіоналів різноманітних спеціальностей, професій, фахів, а по-друге, - в безкомпромісно новітніх технологіях підняття доброякісності проєктування, розроблення та надання туристичних послуг; обговорювання, планування, будування й прогнозування розросту туризму; надання сервісу та мотивування туристів [1, с. 55-56]. Тож, з'ясування проблем, пов'язаних із особливостями корпоративного управління в туризмі, $є$ на часі.

Мета статті полягає у висвітленні питань, пов'язаних із особливостями корпоративного управління в туризмі, специфікою бізнес-етики та корпоративної культури в індустрії гостинності, а також опрацьовуванні їх впливу на стратегію сталого розвитку та конкурентоспроможності готельного підприємства в ринкових умовах міжнародного туристичного бізнес-середовища.

Виклад основного матеріалу дослідження 3 повним обгрунтуванням отриманих наукових результатів. На сьогодні в Україні $\epsilon$ потужний запас для розросту туризму в багатьох напрямах, а саме: гастро-, агро-, етно-, екотуризм; спортивний, рекреаційний, розважальний, науковий, пізнавальний, культурний, освітній і діловий туризм; заходи і фестивалі, свята, MICE (Meetings, Incentives, Conferences, Events) тощо.

Царина гостинності є сукупністю підприємств та організацій, що виконують створення товарів (основоположних та обігових запасів - споруджень, устаткування, продуктів тощо) для інфраструктури гостинності, та комплект секторів та їх підприємств, що безпосередньо надають сервіси гостинності. Гостинність є сукупністю всіх видів функціонування, що продукують матеріальні блага у формі продуктів, енергії, професійної підготовки фахівців для забезпечення сфери гостинності потрібними товарами і кадрами, та безпосереднє надання обслуговувань із гостинності на засадах використання цих товарів. Індустрія гостинності $є$ потужною, багатосторонньою та багатоманітною цариною функціонування, що має на сьогодні динамічне розгортання [2].

Корпоративне управління в галузі гостинності - це керування організаційноправовим оформленням готельного підприємництва, оптимізацією організаційних структур, побудова внутрішньо- i міжфірмових взаємин компанії адекватно до конкретних цілей.

Виокремлюючи корпоративне управління в галузі гостинності в особливий вид, прикмети котрого зумовлено специфікою корпорації як предмета керівництва, його потрібно визначати як управління, побудоване на пріоритетах уподобань акціонерів та їх призначенні в стратегії розвитку корпорації, керівництва, котре ураховує здійснення 
повноважень володіння, що передбачає взаємопрацю акціонерів (корпоративні спілкування), що побудовано на стратегії розросту корпорації загалом (заінтересованість готельного підприємства підконтрольні спільним прихильностям), врешті, це керівництво, котре продукує корпоративну культуру, бізнес-етику, тобто комплект сукупних звичок, установок, цінностей та норм функціонування.

Відповідно до стратегії глобального розвитку, саме восьма мета чіпає галузь туризму, й оголошує до 2030 р.: забезпечення здійснення стратегій сприяння сталому туризму, який схвалює створення нових робочих посад, розвиток місцевої культури, виготовленню місцевої продукції; сприяє економічному зростанню, повній i результативній зайнятості для всіх громадян; допомозі зростання валового внутрішнього продукту (не менше 7\% на рік) у щонайменше розвинутих країнах; підняття продуктивності економіки через диверсифікацію, модернізацію, інноваційну практику [6].

Треба підкреслити, що з миті встановлення цілей в царині сталого розвитку (ЦСР) у вересні 2015 р., не відзначуючи серйозні досягнення в сфері підвищення обізнаності про Порядок денний у галузі сталого розвитку на період до 2030 р., допоки жодна галузь не встигає досягти ніякого з цільових ознак [7]. 3 огляду на це, Організація Об'єднаних Націй $(\mathrm{OOH})$ припускає, що необхідно не тільки впроваджувати належні плани i політику, а й також строїти партнерські взаємозв'язки з урядами, громадянським суспільством і приватним сектором для залучення ресурсів і вироблення новаторських замислів і досвідів для того, щоби перетворити в життя задуми, що позначені в Порядку дня на період до 2030 p.

Прийнятий Глобальний договір ООН містить в власному розпорядженні особливі перспективи для настроювання співробітництва між галузевими ланками та організаціями з метою вироблення шляхів розв'язання глобальних проблем.

Глобальний договір ООН містить заклики до компаній привести свою стратегію і діяльність у відповідність із десятьма спільними домінантами в царині повноважень особистості, трудових взаємовідносин, охорони навколишнього оточення та боріння 3 корупцією, а також спожити заходи для досягнення суспільних цілей і ЦСР.

Прилучаючи до участі тисячі потужних і невеликих корпорацій із усього всесвіту, що відображують відмінні галузі, Організація Об'єднаних Націй бажає зорганізувати справді глобальний рух відповідального підприємництва, котрий керується стремлінням до витримки в особистих основоположних стратегіях i практиці - не лише на благополуччя товариства, а й також заради особистої користі.

Десять принципів Глобального договору ООН, що засновано на фундаментальних договорах і хартіях Організації Об’єднаних Націй, поширені й закріплені в чималих міжурядових ухвалах та підсумкових документах, в тому числі в резолюціях Генеральної Асамблеї. Підприємства гостинності мають дотримуватися цих принципів у власній діяльності та формулюванні стратегій подальшого розвитку та ефективного функціонування.

Розглянемо зміст принципів Глобального договору ООН більш детально:

- відповідно до принципу №1 практичні кола зобов’язані схвалювати та цінувати охорону проголошених на міжнародному рівні повноважень особистості;

- згідно з принципом №2 ділові круги не зобов'язані бути причетні до недотримань повноважень особистості;

- адекватно до принципу №3 діловиті круги зобов’язані схвалювати незалежність союзу та конкретне визнання права на укладення спільних угод;

- щодо принципу №4, то відповідно до нього, ділові круги зобов’язані боротися за руйнування усіх форм насильної та неодмінної роботи;

- згідно 3 принципом №5 діловиті кола повинні виборювати всеосяжне викорінення дитячої роботи; 
- адекватно до принципу №6 ділові круги зобов’язані боротися за знищення дискримінації у галузі труда та зайнятості;

- згідно 3 принципом №7 ділові кола зобов'язані схвалювати підхід до екологічних проблем, заснований на положенні обачливості;

- принцип №8 проголошує, що діловиті круги зобов’язані використовувати починання, цілеспрямовані на підняття відповідальності за становище навколишнього оточення;

- відповідно до принципу №9 ділові круги зобов’язані підтримувати розвиток та поширювання екологічно нешкідливих технологій;

- згідно з принципом №10 діловиті кола повинні протидіяти всім конфігураціям корупції, беручи до уваги також здирство і хабарництво [7].

Відзначуючи все наведене вище, наголосимо, що найшвидшим способом перетворити до 2030 р. всесвіт на щонайліпше, полягає в тому, щоб трансформувати стратегічний переворот і уникнути недовготривалих незначущих партнерських проєктів та зводити тривалі партнерства 3 різноманітними зацікавленими групами й фахівцями туристичної інфраструктури.

Сприяння положенням Глобальної конвенції Організації Об’єднаних Націй уможливлює підприємствам готельної індустрії виробляти продуктивну ідею сталого розросту та конкурентоспроможності готельного виробництва в ринкових умовах туристичного бізнес-середовища, що опирається на продуктивне корпоративне керівництво, бізнес-етику та корпоративну культуру в процесі обслуговувань у галузі гостинності.

Висновки. Таким чином, зазначимо, що проблема ефективного корпоративного керівництва в туризмі, специфіки формулювання задуму бізнес-етики та корпоративної культури, відбору технології надання готельних сервісів, є цінним і неодмінним для сучасного туристичного оточення. Від продуктивності ефективного корпоративного керівництва індустрією гостинності, дотримання домінант Глобального договору Організації Об'єднаних Націй, залежить конкурентоспроможність готельного підприємства в ринкових умовах туристичного бізнес-середовища, а також сталий розріст індустрії гостинності й туризму відповідно до конкретних цілей в царині сталого піднесення.

Подальші дослідження вбачаються у розгляді питань, пов'язаних із методами мотивації персоналу туристичних та готельних підприємств, покращання надання туристичних послуг відповідно до сучасних умов туристичного бізнесу.

Публікацію підготовлено в межі проєкту «Диверсифікація сільського туризму через збалансованість та креативність: поширення європейського досвіду в Україні» / «Diversification of rural tourism through sustainability and creativity: disseminating European experience in Ukraine» (DIRUT) 620720-EPP-1-2020-1-UA-EPPJMO-MODULE за підтримки Програми Erasmus+: Jean Monnet Європейського Союзу, що реалізується у Запорізькому національному університеті (2020-2023).

\section{Список бібліографічного опису:}

1. Безкоровайна Л. В. Теоретичні і методичні засади професійної підготовки майбутніх фахівців з туризмознавства у вищих навчальних закладах: дис. ... д-ра пед. наук: 13.00.04 / Запорізький національний університет. Запоріжжя, 2018. $713 \mathrm{c}$

2. Мартієнко А.І., Дишкантюк О.В. Сутність гостинності як економічної категорії. Економіка: реалії часу. Науковий журнал. 2017. № 2 (30). С. 72-78. URL: http://economics.opu.ua/files/archive/2017/No2/72.pdf

3. Про схвалення Концепції популяризації України у світі та просування інтересів України у світовому інформаційному просторі від 11 жовтня 2016 р. № 739-p Київ. URL: https://www.kmu.gov.ua/ua/npas/249407991

4. Про схвалення Стратегії розвитку туризму та курортів до 2026: розпорядження Кабінету Міністрів України від 16.03.2017 p. №168-p. Урядовий портал. 2017. № 168-2017-p. URL: https://www.kmu.gov.ua/ua/npas/249826501

5. Про туризм: Закон України від 15.09.1995 р. № 324/95-ВР. Відомості Верховної Ради України. 1995. № 31. Ст. 241. Із змінами, внесеними згідно із Законом № 222-VIII (222-19) від 02.03.2015 р., Відомості Верховної Ради України. 2015. № 23. ст. 158. URL: http://zakon2.rada.gov.ua/laws/show/1282-15

6. Resolution adopted by the General Assembly on 22 December 2015 (2015). Global Code of Ethics for Tourism. 
7. United Nations. URL: https://www.un.org/en

\section{References:}

1.Bezkorovaina L. V. (2018) Theoretical and methodological basis of the professional training of the future masters of tourism in higher educational institutions Thesis for a doctoral degree in pedagogical sciences, Zaporizhzhia: Zaporizhzhia National University. [in Ukrainian]

2.Martiienko A., Dyshkantiuk O. (2017) Sutnist hostynnosti yak ekonomichnoi katehorii. Ekonomika: realii chasu. Naukovyi zhurnal. № 2 (30). P. 72-78. [in Ukrainian]

3.Pro skhvalennja Koncepciji populjaryzaciji Ukrajiny u sviti ta prosuvannja interesiv Ukrajiny u svitovomu informacijnomu prostori (2016) [On approval of the Concept of popularization of Ukraine in the world and promotion of Ukraine's interests in the world information space] Kyjiv. [in Ukrainian]

4.Pro skhvalennja Strateghiji rozvytku turyzmu ta kurortiv do 2026 (2017) [On approval of the Strategy for the development of tourism and resorts until 2026], Kyjiv. [in Ukrainian]

5.Pro turyzm (1995) [About tourism] Zakon Ukrajiny, Kyjiv. [in Ukrainian]

6.Resolution adopted by the General Assembly on 22 December 2015 (2015). Global Code of Ethics for Tourism.

7.United Nations. URL: https://www.un.org/en

Дата подання публікації 22.07.2021 р. 